\title{
Occult Hepatitis C Virus Infection in Candidates for Liver Transplant With Cryptogenic Cirrhosis
}

\author{
Hossein Keyvani ${ }^{1}$, Farah Bokharaei-Salim ${ }^{1, *}$, Seyed Hamidreza Monavari ${ }^{2}$, Maryam Esghaei \\ ${ }^{1}$, Mohssen Nassiri Toosi ${ }^{3}$, Shahin Fakhim ${ }^{4}$, Zohreh-Azita Sadigh ${ }^{5}$, Seyed Moayed Alavian ${ }^{6}$ \\ ${ }_{2}^{1}$ Department of Virology, Iran University of Medical Sciences, Tehran, IR Iran \\ 2 Department of Virology and Anti-Microbial Resistant Research Center, Iran University of Medical Sciences, Tehran, IR Iran \\ ${ }_{4}^{3}$ Department of Gastroenterology, Imam Khomeini Hospital, Tehran University of Medical Sciences, Tehran, IR Iran \\ 4 Department of Civil Engineering, Islamic Azad University, Shahre Qods, Tehran, IR Iran \\ 5 Department of Civil Engineering, Islamic Azad University, \\ 6 Razi Vaccine and Serum Research Institute, Karaj, IR Iran \\ ${ }^{*}$ Corresponding author: Farah Bokharaei-Salim, Department of Virology, Iran University of Medical Sciences, Tehran, IR Iran. Tel/Fax: +98-2188602205, E-mail: bokharaeifarah@gmail. \\ com.
}

Received: March 23, 2013; Revised: Jun 27, 2013; Accepted: July 03, 2013

\begin{abstract}
Background: Occult hepatitis C virus (HCV) infection is a new entity described by the presence of HCV-RNA in liver biopsy and/or peripheral blood mononuclear cell (PBMC) specimens, and undetectable levels or absence of HCV-RNA and in the absence or presence of anti HCV antibodies in plasma by current laboratory methods.

Objectives: To evaluate the detection of HCV-RNA in PBMC specimens of the liver transplant candidates with cryptogenic cirrhosis by reverse transcriptase-nested polymerase chain reaction (RT-nested PCR).

Patients and Methods: From November 2007 to March 2013, 45 patients from Liver Transplant Center of Imam Khomeini Hospital, Tehran, were enrolled in this cross sectional study. PBMC specimens were separated from the peripheral blood sample. After extraction of RNA from plasma and PBMC specimens, HCV-RNA status was tested by RT-nested PCR. The $5^{-}$-untranslated region (5 $5^{\circ}$-UTR) genotyping of HCV-RNA amplified from PBMC specimens was performed by a standard methodology with the INNO-LiPA ${ }^{\mathrm{TM}}$ HCV II kit. The PCR products of $5^{\prime}$-UTR were sequenced after cloning into the pJET1.2 / blunt cloning vector.

Results: Of 45 patients, 4 (8.9\% [95\% CI: 4.4-15.6]) had detectable genomic HCV-RNA in their PBMC specimens. HCV genotypes were determined in the PBMCs of these subjects showed that 2 (50.0\%) subjects with occult HCV infection had HCV subtype 3a, and 2 (50.0\%) had HCV subtype $1 \mathrm{~b}$.

Conclusions: This study found that $8.9 \%$ of the Iranian candidates for liver transplant with cryptogenic cirrhosis had occult HCV infection. Therefore, designing prospective studies focusing on the diagnosis of occult HCV infection in these subjects prior to liver transplantation could be valuable.
\end{abstract}

Keywords: Hepatitis C Virus; Occult Infection; Peripheral Blood Mononuclear Cells; Cryptogenic; Cirrhosis; Liver Transplantation

\section{Background}

Cirrhosis of the liver determined as a chronic, progressive, and degenerative disease, described by structurally abnormal nodules and fibrosis in the liver (1). Liver cirrhosis usually identified as cryptogenic cirrhosis, a number of possible recognizable etiologies must be first excluded such as viral hepatitis, alcohol abuse, autoimmune hepatitis, nonalcoholic steatohepatitis (NASH), Wilson's disease, biliary tract disease, hepatotoxic drug, thyroid dysfunction, decompensated diabetes, haemochromatosis, any severe systemic disease, etc. The frequency of cryptogenic hepatitis is reported to be 5.4\% (2). Approximately, $3-30 \%$ of patients with cirrhosishave cryptogenic cirrhosis (3-5), and its prevalence is reported to vary from
$3-14 \%$ in adults to $22 \%$ in children (2). This disease is the fourth indication for liver transplantation and about 7-14 $\%$ of the recipients receive transplants for this etiology (6, 7 ). The diagnosis of cryptogenic cirrhosis has significantly decreased, following the discovery of viral hepatitis (8). Cryptogenic cirrhosis or cirrhosis of unknown etiology is probably a representation of the endpoint of several different occult hepatic disorders. It is an important clinical entity as patients with cryptogenic cirrhosis can develop hepatocellular carcinoma (HCC) (9). Many studies have been conducted to find an etiology for cryptogenic liver disease and recently, the importance of hepatitis $\mathrm{C}$ infection as a cause of liver disease with unknown etiology and hepatocellular carcinoma (HCC) has been dis-

Implication for health policy/practice/research/medical education:

This study is a research article for finding occult Hepatitis C Virus Infection in Candidates for Liver Transplant with Cryptogenic Cirrhosis.

Copyright @ 2013, Kowsar Corp.; Licensee Kowsar Ltd. This is an Open Access article distributed under the terms of the Creative Commons Attribution License(http:/ creativecommons.org/licenses/by/3.0), which permits unrestricted use, distribution, and reproduction in any medium, provided the original work is properly cited. 
cussed, thus, it is important to clarify the role of infection with this virus in cirrhosis with unknown etiology.

Hepatitis C virus is an important pathogen which chronically infects nearly $2.2 \%$ of the world population (10). Iran has low endemicity for HCV infection and less than $0.2 \%$ of the general populations are infected with HCV (11). In about $85 \%$ of the cases chronic HCV infection is established. Chronic hepatitis $\mathrm{C}$ progresses to cirrhosis in up to $35 \%$ of the patients and approximately $3 \%$ of these patients would eventually develop HCC (12). In January 2004, a new entity of HCV infection, which was called occult HCV infection, was described in patients with cryptogenic hepatitis (13). Occult HCV infection, characterized as the presence of genomic HCV RNA strand in liver biopsy and peripheral blood mononuclear cell (PBMC) specimens in the absence of detectable level of HCV RNA in plasma by current laboratory methods, and in the absence or presence of anti HCV antibodies. This occult infection has been reported in individuals with or without chronic liver disease with unknown etiology, in several at risk groups for $\mathrm{HCV}$ infection, and also in general population without any evidence of liver disease $(13,14)$. Hepatitis $C$ virus is essentially hepatotropic, and hepatocytes are the main site for $\mathrm{HCV}$ replication. The intermediary of replication of this virus is a negative-strand RNA. There is some evidence of the presence of negative chain HCV RNA in PBMCs which is not detected in plasma. Furthermore, the virus multiplying has been demonstrated in these cells of individuals with occult HCV infection (15).

End-stage liver disease (ESLD) secondary to cryptogenic cirrhosis is one of the most important indications for liver transplantation (LT) (7). The liver biopsy always plays a critical role in the management of individuals with a diagnostic difficult situation for instance the patients with abnormal liver tests with unknown etiology or having a specific liver disease (4). Although the best and most reliable technique to diagnosis occult HCV infection is testing of genomic HCV RNA strand in the liver biopsy specimens, detection of HCV RNA in PBMC specimens is a valuable method when the liver biopsy could not be performed (16).

\section{Objectives}

The main purpose of the present study was to detect the presence of genomic HCV RNA strand in PBMC specimens of the liver transplant Iranian candidates with cryptogenic cirrhosis.

\section{Patients and Methods}

\subsection{Study Population}

Forty five consecutive individuals with established cirrhosis with unknown etiology under observe of the liver transplant center of Imam Khomeini Hospital affiliated with Tehran University of Medical Sciences, Tehran Iran, were investigated from November 2007 to March 2013 in this cross sectional study by using Census method. The diagnosis of liver cirrhosis with unknown etiology was made after a comprehensive evaluation failed to identify a specific etiology. After explaining the study protocol, a written consent form was obtained from each patient. The present study was approved by the local ethics committee of Iran University of Medical Sciences.

Patients with established cryptogenic cirrhosis were screened for inclusion in the present study. The severity of the patients liver disease was scored according to the Model for End stage of Liver Disease (MELD), and the Child-Pugh classification. The inclusion criteria were as follows:1) ultrasound showing a diffusely echogenic liver; 2) having normal or elevated ALT (more than 1.5 times);3) all the patients had negative results for serum genomic HCV RNA and anti-HCV (tested at least three times before the entry to the study);4) Patients exclusion criteria were all known causes of cirrhosis; for instance: alcohol abuse (>20 g/day), infection with hepatitis C virus (plasma HCV RNA and anti-HCV positive), infection with hepatitis $B$ virus [plasma HBV DNA, hepatitis B surface antigen (HBsAg), hepatitis B e antigen (HBeAg), hepatitis B core antibody (HBcAb), and hepatitis B e antibody (HBeAb) positive], autoimmune hepatitis, genetic disorders, Wilson's disease, drug toxicity, NASH, haemochromatosis, biliary obstruction and primary biliary cirrhosis, presence of any severe systemic illness, malignancies, and positive results for anti-human immunodeficiency virus antibodies (anti-HIVAbs).

\subsection{Collection and Preparation of the Samples}

A peripheral blood sample from each patient was collected in an EDTA-containing sterile tube. After separation of plasma by centrifugation, it was stored at $-80^{\circ} \mathrm{C}$ for experiments. The PBMCs of the samples were isolated by Ficoll Hypaque (FH) gradient centrifugation (Lympholyte-H, Cedarlane, Canada). The pellet of PBMCs was washed for more than three times using phosphatebuffered saline $(\mathrm{PH}=7.3 \pm 0.1)$. The cells were counted and after adding RNALater (Ambion Inc., Austin, TX) solution, were stored at $-80^{\circ} \mathrm{C}$ until use. Plasma and PBMC specimens from 10 consecutive blood donors as well as $10 \mathrm{pa}-$ tients with established chronic HCV infection were used as negative and positive controls, respectively. Also, the patients who had an occult HCV infection undertook two extra peripheral blood samplings every three months for following up the patients.

\subsection{Isolation of RNA and Detection of the Genomic HCV RNA Using Reverse Transcriptase-Nested Poly- merase Chain Reaction (RT-nested PCR) Method \\ RNA was extracted from plasma and a pellet of about 3-5 $\times 10^{6}$ PBMC specimens using High Pure Viral Nucleic Acid Kit (Roche Diagnostics GmbH, Mannheim, Germany) ac-}


Keyvani $H$ et al.

cording to the manufacturer's instructions. Genomic HCV RNA in plasma and PBMC specimens was detected by RT-nested PCR method. cDNA synthesis from RNA and two-stage PCR were performed as previously described in detail (17). The PCR products of specimens with appropriate controls and the DNA size marker (100 bp) were visualized on $1.5 \%$ agarose gel stained with the fluorescent dye ethidium bromide followed by electrophoresis (Figure 1).

Figure 1. Result of HCV RNA Detection by RT Nested-PCR Method

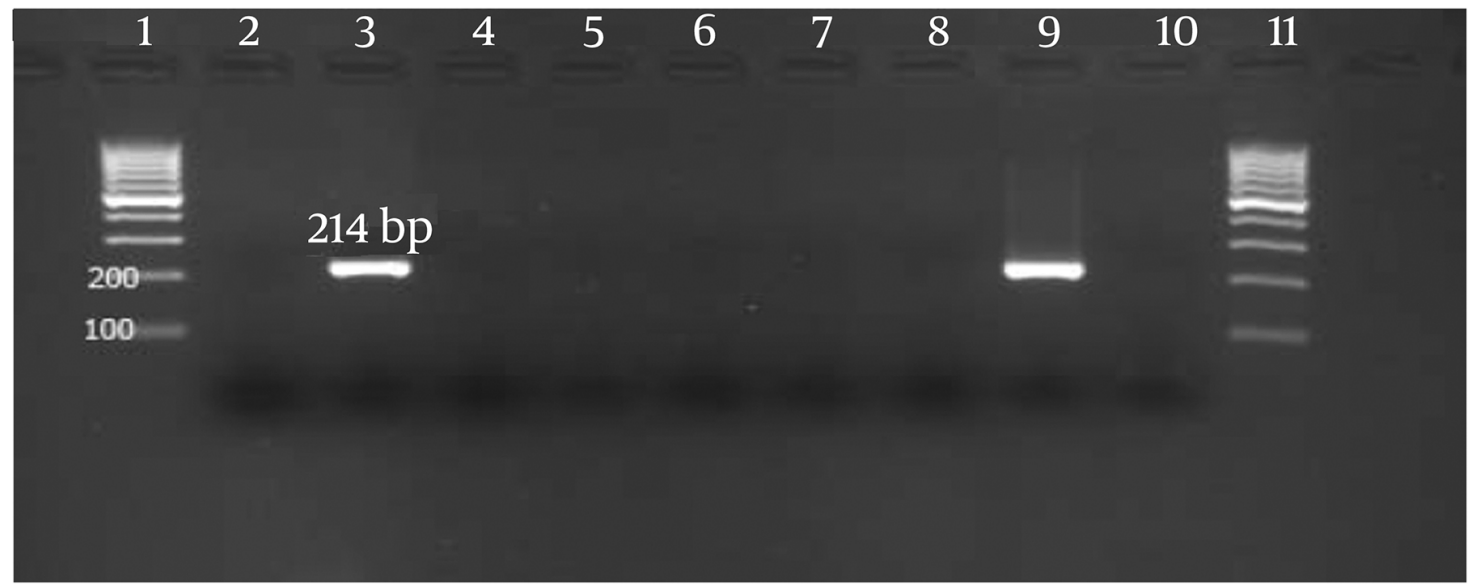

Lane1: 100 bp DNA ladder, Lane 2: PCR products of first patient's serum, Lane 3: PCR products of first patient's PBMCs, Lane 4: PCR products of second patient's serum, Lane 5: PCR products of second patient's PBMCs, Lane 6: Negative control in RT round PCR, Lane 7: Negative control in first round PCR, Lane 8: Negative control in second round PCR, Lane 9: HCV RNA positive control, Lane 10: HCV RNA negative control, Lane 11: 100 bp DNA ladder.

The sensitivity limit of the PCR amplification method for detection of genomic HCV RNA strand was $40 \mathrm{IU} / \mathrm{ml}$ plasma. The sensitivity was determined by testing serial dilutions of a plasma specimen with a known viral load [determined using Cobas TaqMan 48 Analyzer (Roche, Germany)].

\subsection{HCV Genotyping by INNO-LiPA}

Total RNA was extracted from plasma and PBMC specimens as described above. The $5^{-}$-UTR genotyping of HCV RNA amplified from PBMC specimens was performed by the INNO-LiPA ${ }^{\mathrm{TM}}$ HCV II kit (Innogenetics, Ghent, Belgium) according to the manufacturer's instructions. This HCV genotyping was also confirmed by sequencing $5^{\prime}$ UTR fragments after the PCR products were cloned into the pJET1.2/blunt cloning vector (Fermentas, St. Leon-Rot, Germany) as described elsewhere $(17,18)$ (Figure 2).

\subsection{Enzyme Immunoassay (EIA) and Western Blot Assay for Detection of Anti-HCV Antibodies}

Anti-HCV antibodies were determined by two different commercial enzyme-linked immunosorbent assay (ELISA) kits: a forth generations test [INNOTEST-HCVAb IV (Innogenetics, Ghent, Belgium)], and a third generation test [ACON Laboratories, San Diego, CA]. Western blot assay was performed using HCV BLOT 3.0 (MP Diagnostics, Germany) according to the manufacturer's instructions.

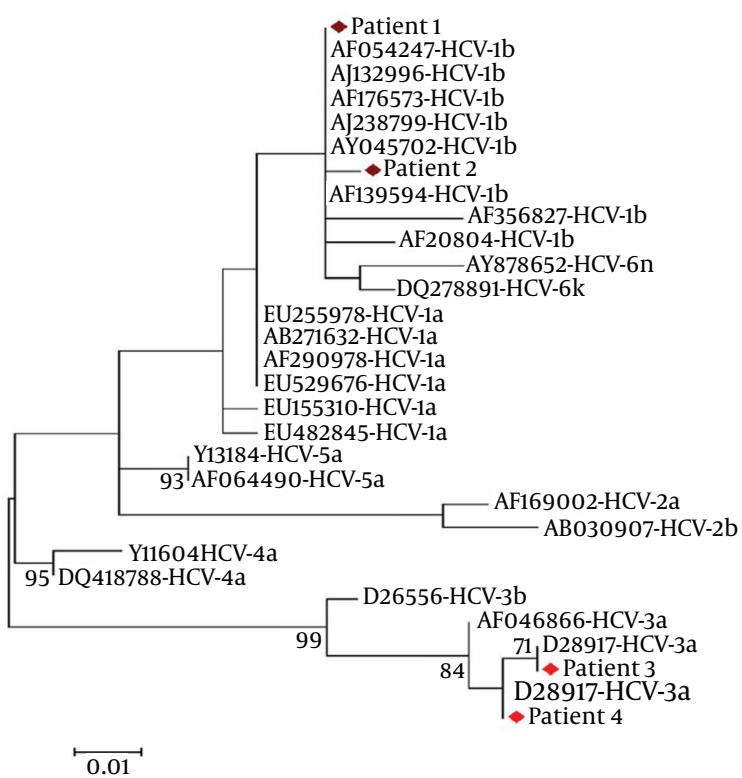

Figure 2. Neighbor-joining tree constructed with HCV $5^{\prime}$-untranslated region ( $5^{-}$-UTR) nucleotide sequences of the clones obtained from 4 individuals with occult HCV infection, and sequences corresponding to different HCV genotypes retrieved from GenBank. Bootstrap values $\geq 70$ obtained after 1000 replicates of the data sheet, has been shown in the nodes of the tree. 
Keyvani $\mathrm{H}$ et al.

\subsection{Statistical Analysis}

The statistical analyses were performed by Chi Square and Fisher's exact tests . Analysis of continuous variables was performed using Student's t-test and Mann-Whitney U. The Kolmogorov-Smirnov test was used for checking the normal distribution of the data. The descriptive statistical indexes including standard deviation, mean, confidence interval at $95 \%$. P value of $\leq 0.05$ was considered to be statistically significant. All data were analyzed using SPSS version 17 (SPSS, Chicago, IL, USA).

\section{Results}

Forty five individuals with established cryptogenic cirrhosis, whose results for plasma HCV RNA strand and anti-HCV antibodies testing were repeatedly negative, were recruited in this cross sectional study. The mean age of participants was $41.4 \pm 12.4$ (range 19-64 years). Of 45 patients, 33 (73.3\%) were male. All patients had negative findings for antibodies against HCV and genomic HCV RNA in their plasma specimen. The complete information of the participants with established cryptogenic cirrhosis is summarized in Table 1.

\begin{tabular}{|c|c|c|c|c|}
\hline Characteristics & Total & Negative & Positive & Pvalue \\
\hline No. & 45 & 41 & 4 & \\
\hline Gender Male/Female & $33 / 12$ & $30 / 11$ & $3 / 1$ & $0.917^{\mathrm{a}}$ \\
\hline Age, $y$ & $41.7 \pm 12.3(19-64)$ & $40.8 \pm 12.5$ & $50.8 \pm 5.8$ & $0.019^{b}$ \\
\hline Body-Mass-Index (BMI), kg/m2 & $24.2 \pm 5.6(16.9-39.1)$ & $24.2 \pm 5.8$ & $23.9 \pm 2.3$ & $0.196^{\mathrm{b}}$ \\
\hline \multicolumn{5}{|l|}{ Laboratory Parameters, Mean \pm SD } \\
\hline White Blood Cell & $\begin{array}{l}4252.0 \pm 1979.6(1500- \\
9600)\end{array}$ & $4179.8 \pm 1819.0$ & $4975.0 \pm 3519.8$ & $0.036^{\mathrm{b}}$ \\
\hline Hemoglobin, gr/dl & $12.2 \pm 1.8(8.4-15.5)$ & $12.3 \pm 1.9$ & $11.0 \pm 3.0$ & $0.080^{\mathrm{b}}$ \\
\hline Alanine aminotransferase, IU/L & $48.6 \pm 38.4(10.0-210.0)$ & $42.9 \pm 24.0$ & $105.8 \pm 94.3$ & $<0.001^{\mathrm{b}}$ \\
\hline Aspartate aminotransferase, IU/L & $65.6 \pm 60.8(4.8-380.0)$ & $61.1 \pm 56.6$ & $110.8 \pm 91.0$ & $0.331^{\mathrm{b}}$ \\
\hline alkaline phosphatase, IU/L & $\begin{array}{l}309.3 \pm 149.6(74.0- \\
770.0)\end{array}$ & $301.7 \pm 142.5$ & $385.50 \pm 220.0$ & $0.317^{b}$ \\
\hline Bilirubin Total, mg/dl & $2.8 \pm 2.8(0.6-17.2)$ & $2.8 \pm 3.0$ & $2.7 \pm 1.2$ & $0.595^{\mathrm{b}}$ \\
\hline Bilirubin Direct, mg/dl & $0.8 \pm 1.1(0.1-6.9)$ & $0.9 \pm 1.1$ & $0.6 \pm 0.3$ & $0.829^{\mathrm{b}}$ \\
\hline Cholesterol, mg/dl & $161.3 \pm 34.4(103.0-241.0)$ & $160.3 \pm 32.3$ & $171.8 \pm 57.0$ & $0.095^{\mathrm{b}}$ \\
\hline Triglyceride, mg/dl & $107.1 \pm 39.4(45.0-211.0)$ & $108.5 \pm 40.2$ & $93.5 \pm 32.7$ & $0.667^{b}$ \\
\hline Iron, $\mathrm{mg} / \mathrm{dl}$ & $76.1 \pm 51.5(8.0-202.0$ & $77.1 \pm 53.8$ & $65.8 \pm 14.5$ & $0.031^{b}$ \\
\hline Ferritin, mg/dl & $87.9 \pm 141.3(5.0-750.0)$ & $73.0 \pm 101.7$ & $237.8 \pm 345.0$ & $0.239^{\mathrm{b}}$ \\
\hline Platelet & $\begin{array}{l}78431.8 \pm 65373.8(12000- \\
352000)\end{array}$ & $81825.0 \pm 66935.0$ & $44500.0 \pm 36391.4$ & $0.604^{\mathrm{b}}$ \\
\hline Prothrombin Time, Sec & $17.0 \pm 3.2(12.0-26.7)$ & $17.1 \pm 3.3$ & $15.8 \pm 2.4$ & $0.423^{b}$ \\
\hline INR & $1.7 \pm 0.6(1.0-3.6)$ & $1.8 \pm 0.6$ & $1.5 \pm 0.4$ & $0.366^{\mathrm{b}}$ \\
\hline \multicolumn{5}{|l|}{ Epidemiological Parameters, No. (\%) } \\
\hline History of Surgery & $33(73.3)$ & $30(73.2)$ & $3(75.0)$ & $0.938^{\mathrm{a}}$ \\
\hline History of dental operation & $28(62.2)$ & $26(63.4)$ & $2(50.0)$ & $0.601^{\mathrm{a}}$ \\
\hline History of jaundice & $6(13.3)$ & $5(12.2)$ & $1(25.0)$ & $0.465^{\mathrm{a}}$ \\
\hline History of blood transfusion & $21(46.7)$ & $17(41.5)$ & $4(100.0)$ & $0.027^{\mathrm{a}}$ \\
\hline History of endoscopy & $44(97.8)$ & $40(97.6)$ & $4(100.0)$ & $0.754^{\mathrm{a}}$ \\
\hline History of war injury & $4(8.9)$ & $3(7.3)$ & $1(25.0)$ & $0.241^{\mathrm{a}}$ \\
\hline Hospital admission & $42(93.3)$ & $29(70.1)$ & $4(100.0)$ & $0.581^{\mathrm{a}}$ \\
\hline $\begin{array}{l}\text { History of travel to the endemic } \\
\text { area }\end{array}$ & $9(20.0)$ & $5(12.2)$ & $4(100.0)$ & $<0.001^{\mathrm{a}}$ \\
\hline
\end{tabular}

\footnotetext{
a P value base on Fisher Exact test
}

$\mathrm{b}$ P value base on Mann-Whitney U test 
Keyvani $H$ et al.

The genomic HCV RNA was detected in PBMCs from $4(8.9 \%)$ of the 45 patients who have cirrhosis with unknown etiology. Therefore, these patients had an occult $\mathrm{HCV}$ infection. For confirmation of positive results, these patients undertook two extra peripheral blood samplings every three months. The presence of genomic HCV RNA strand in plasma and PBMC specimens was tested again in these patients, which the Preliminary results were confirmed. The HCV genotyping was performed by the INNOLiPA $^{\mathrm{TM}}$ HCV II kit in PBMC specimens of the patients with occult HCV infection showed that 2 (50\%) patients were infected with HCV subtype 3a, and 2 (50\%) with HCV subtype $1 \mathrm{~b}$. The results of the HCV genotyping of the patients with occult HCV infection using the INNO- LiPA ${ }^{\mathrm{TM}} \mathrm{HCV}$ II kit was confirmed by the nucleotide sequence analysis of the HCV $5^{\prime}$-UTR.

The plasma of all the individuals with occult HCV infection was examined twice for detection of anti-HCV Abs with two different commercial kits. None of them had positive results for anti-HCV Abs in their plasma. The presence of anti-HCV Abs was tested in the individuals' plasma with occult HCV infection by a third-generation recombinant immunoblot assay; one of 4 individuals with occult HCV infection had anti-HCV Abs to NS3-2 antigen and therefore, the results of western blot assay in these patients were indeterminate.

In this cross sectional study, significant differences were seen in the age $(\mathrm{P}=0.02)$, white blood cell count $(\mathrm{P}=0.04)$, alanine aminotransferase $(\mathrm{P}<0.001)$, iron $(\mathrm{P}=0.03)$, history of blood transfusion ( $\mathrm{P}=0.03)$, and history of travel to the endemic area $(\mathrm{P}<0.001)$ between patients with positive and negative results for occult HCV infection (Table 1).

\section{Discussion}

The recurrence of the HCV infection is one of the most important problems following liver transplantation which leads to a decrease in patient and graft failure (19). Therefore, identification of patients with HCV infection for treatment planning before and after liver transplantation is critical. Newly, occult HCV infection has been characterized as the presence of genomic HCV RNA in liver biopsy specimen and in nearly $70 \%$ of the cases in PBMC specimens despite undetectable genomic HCV RNA as well as antibodies against HCV in the plasma (13). The current study was primarily aimed at determining the presence of HCV RNA in PBMC specimens of the patients with cryptogenic cirrhosis who were candidates for liver transplant. The genomic HCV RNA was detected in PBMCs of $4(8.9 \%)$ of 45 patients, therefore, these patients had occult HCV infection. The HCV genotyping of HCV RNA detected in PBMCs of individuals with occult HCV infection showed that $2(50.0 \%)$ patients were infected with HCV subtype 3a, and 2 (50.0\%) with HCV subtype 1 b. Despite the fact that occult HCV infection has been recently found, this infection has been reported from various parts of the world for instance: it was seen in individuals with cryptogenic liver disease in Spain (57\%) (13), in Egypt (10\%) (20), in Pakistan (74\%) (21), In Iran (10.1\%) (17), in individuals with Cryptogenic cirrhosis with HCC in Italy (40\%) (22), in haemodialysis patients in (45\%) in Spain (16), patients with lymphoproliferative disorders in Iran (1.9\%) (18), in the general population (3.3\%) in Italy (23), in population free of clinically detectable infectious liver disease (1.27\%), and in patients with active HBV infection (28\%) in Italy (24). However, there are also several reports which scientists have not been able to trace the occult HCV infection, such as in mixed cryoglobulinemia (25), non-Hodgkin lymphoma (26), and autoimmune disorders (27). So it seems that more studies in this field on various groups with high population size are needed.

Occult HCV infection is distributed all over the world and it seems that all of the HCV genotypes are involved in this infection. In the preliminary studies on the occult HCV infection the only HCV subtype isolated was $1 \mathrm{~b}(13$, 16). However, subsequent studies have revealed occult HCV infection belonging to HCV subtypes $1 \mathrm{a}, 1 \mathrm{~b}, 2 \mathrm{a}, 3 \mathrm{a}, 3 \mathrm{~b}$, $6 f(14,17,21)$. The most prevalent HCV genotypes circulating throughout Iran are 1a (44.9\%) followed by subtype 3a (39.6\%), and $1 \mathrm{~b}(11.3 \%)$ (28). We detected only HCV subtypes $3 \mathrm{a}$ and $1 \mathrm{~b}$ in our study population, despite the most abundant HCV genotype in Iran is 1a. Thus it seems that more studies in this field are needed with large population size. On the other hand, it has been reported that different HCV genotypes are detected in PBMC specimens as compared to plasma of the patients with occult HCV infection, or HCV infection $(15,23)$. The prevalence rate of occult HCV infection in the present study (8.9\%) was compatible with the prevalence rate of occult HCV infection in Iranian patients (10.1\%) with cryptogenic liver disease (17) and it is several times of the prevalence of HCV infection in general population (0.2\%) of Iran (11). Thus it seems that this type of infection (occult HCV infection) should be considered, and blood transfusion may never be completely risk-free. Although screening for infectious diseases has significantly improved the safety of blood transfusion, the risks of transfusion of different blood borne diseases (such as hepatitis C and B, HIV/ AIDS, and etc.) have not been eliminated (23). The risk of $\mathrm{HCV}$ infection has considerably reduced because of more sensitive and reliable nucleic acid testing (29); however, due to their costs, they are not widely used in developing countries. These countries routinely check for antibodies to this virus; thus, the test cannot recognize HCV infection that occurs among the time of exposure to the infection and emergence of antibodies to the virus (known as the window period) $(23,29)$.

There are different risk factors for HCV infection such as transfusion history, unsafe injections, tattooing, intravenous drug abuse, razor blade shaving by barbers, and extramarital sexual contacts. There are a lot of studies 
demonstrating that contact with contaminated blood and other body fluids occur in a variety of occupations. Health care workers and public safety personnel can be exposed to blood through needle sticking and other sharps injuries, and skin exposures. One of the most important pathogens that can infect humans through these ways is $\mathrm{HCV}(30,31)$. Interestingly, significant differences were seen in a history of blood transfusion, and history of travel to the endemic area among individuals with and without occult HCV infection. Thus, this infection may be a result of transmission from contaminated blood or contact of an injured tissue with blood or body fluids. Also a significant difference was observed in the age between individuals with and without occult HCV infection. This is probably due to exposure to the infection by various pathogens with increasing the age. It has been reported that there is a potential transmission risk of occult HCV infection because of finding high occult HCV infection frequency between family members of occult HCV positive patients (32). This is likely due to the presence of the virus in peripheral blood mononuclear cells of patients with occult HCV infection. So the likelihood of transmission of the HCV infection in the blood transfusion and bone marrow and organ transplantation is considered. It was also reported that nearly $20 \%$ of individuals with positive results for HCV undergoing liver transplant likely develop liver cirrhosis in up to 5 years, and in about $50 \%$ of cases probably develop liver cirrhosis within a decade (19). Therefore, identification of occult HCV infection and HCV infection before liver transplantation for patients and physicians has particular importance. Also, the reactivation of HCV infection is well known in immunocompromised patients or individuals receiving immunosuppressive therapy (33). There is a case report that revealed occult HCV infection may play a critical role as an agent of liver failure in transplanted patients (34). Thus, the risk of HCV transmission should be considered in liver transplantation and it seems that performing the test to detect infection prior to liver transplantation is important and necessary.

Due to the lack of antibodies to the HCV in plasma of patients with occult $\mathrm{HCV}$ infection detection of antibodies against HCV is not distinguishing. In the present study, we tested plasma samples for detection of anti-HCV Abs with two commercial enzyme immunoassay kits. The results showed that all 45 patient's plasma samples which were tested for anti-HCV Abs had negative results ; thus, the results were compatible with previous reports (35). All 4 plasma specimens of patients with occult HCV infection were also examined for detection of anti-HCV Abs by a third generation recombinant immunoblot assay (RIBA). This test has been used for confirming samples with positive findings for HCV antibodies by enzyme immunoassay and positive results of RIBA for detection of anti-HCV Abs is usually related to HCV viremia (36). In the present study, one (25.0\%) of 4 patients with occult HCV infection had anti-HCV Abs to NS3-2 antigen. However, this patient had antibody reacting to a single recombinant HCV antigen and therefore the result was determined as indeterminate. This finding could be important, but further research is required. In the present study we tested only 45 patients, because the number of these patients is too low, and finding them is time consuming. Thus, according to the results of the present study, the occult HCV infection should be considered in the liver transplant candidates with cryptogenic cirrhosis, and it seems that a multicenter study with a larger sample size is necessary to confirm the presence of this infection.

In conclusion, the present study demonstrated that more than $8.9 \%$ of liver transplant candidates with cryptogenic cirrhosis had occult HCV infection. So, HCV RNA detection is recommended in PBMC samples of the individuals with cryptogenic cirrhosis prior to liver transplantation especially in patients who are suspected to occult HCV infection. Finally, future studies should be performed to consider the possibility of this infection in various groups of the community who have been associated with the infectious agents transmitted through blood.

\section{Acknowledgements}

We wish to thank all of our associates who actively participate in the present study.

\section{Authors' Contribution}

HK, FBS designed the study and were responsible for the overall study management. FBS, ME, and ZAS organized the analysis. FBS, SHRM, SHF and SMA prepared the manuscript. MNT introduced the patients. All authors contributed to the final version of the manuscript.

\section{Financial Disclosure}

The authors have no financial disclosures to declare and no conflicts of interest to report.

\section{Funding/Support}

The present study was supported by the Research Deputy of Iran University of Medical Sciences, grant number 18118.

\section{References}

1. Anthony PP, Ishak KG, Nayak NC, Poulsen HE, Scheuer PJ, Sobin LH. The morphology of cirrhosis: definition, nomenclature, and classification. Bull World Health Organ. 1977;55(4):521-40.

2. Czaja AJ. Cryptogenic Chronic Hepatitis and Its Changing Guise in Adults. Dig Dis Sci. 2011

3. Caldwell SH, Oelsner DH, Iezzoni JC, Hespenheide EE, Battle EH, Driscoll CJ. Cryptogenic cirrhosis: clinical characterization and risk factors for underlying disease. Hepatology. 1999;29(3):664-9.

4. Rockey DC, Caldwell SH, Goodman ZD, Nelson RC, Smith AD. Liver biopsy. Hepatology. 2009;49(3):1017-44.

5. Saunders JB, Walters JR, Davies AP, Paton A. A 20-year prospective study of cirrhosis. Br Med J (Clin Res Ed).1981;282(6260):263-6.

6. Belle SH, Beringer KC, Detre KM. An update on liver transplanta- 
tion in the United States: recipient characteristics and outcome. Clin Transpl.1995:19-33.

7. Charlton MR, Kondo M, Roberts SK, Steers JL, Krom RA, Wiesner RH. Liver transplantation for cryptogenic cirrhosis. Liver Transpl Surg. 1997;3(4):359-64.

8. Desai HG. Cryptogenic cirrhosis: a vanishing entity. J Assoc Physicians India. 2009;57:751-4.

9. Al-Mahtab M, Rahman S, Khan M. Occult Hepatitis B Virus Related Decompensated Cirrhosis of Liver in Young Males: First Report of Two Cases from Bangladesh. Hepatitis Monthly. 2008;8(2):147-50.

10. Global burden of disease (GBD) for hepatitis C.J Clin Pharmacol. 2004;44(1):20-9.

11. Alavian SM, Ahmadzad-Asl M, Lankarani KB, Shahbabaie MA, Bahrami Ahmadi A, Kabir A. Hepatitis C Infection in the General Population of Iran: A Systematic Review. Hepat Mon. 2009;9(3):211-23.

12. Pham TN, Michalak TI. Occult persistence and lymphotropism of hepatitis C virus infection. World J Gastroenterol. 2008;14(18):278993.

13. Castillo I, Pardo M, Bartolome J, Ortiz-Movilla N, Rodriguez-Inigo $\mathrm{E}$, de Lucas $\mathrm{S}$, et al. Occult hepatitis $\mathrm{C}$ virus infection in patients in whom the etiology of persistently abnormal results of liverfunction tests is unknown. J Infect Dis. 2004;189(1):7-14

14. Carreno V, Bartolome J, Castillo I, Quiroga JA. New perspectives in occult hepatitis C virus infection. World J Gastroenterol. 2012;18(23):2887-94

15. Bokharaei Salim F, Keyvani H, Amiri A, Jahanbakhsh Sefidi F, Shakeri R, Zamani F. Distribution of different hepatitis $C$ virus genotypes in patients with hepatitis $\mathrm{C}$ virus infection. World J Gastroenterol.2010;16(16):2005-9.

16. Barril G, Castillo I, Arenas MD, Espinosa M, Garcia-Valdecasas J, Garcia-Fernandez N, et al. Occult hepatitis C virus infection among hemodialysis patients. J Am Soc Nephrol. 2008;19(12):228892.

17. Bokharaei-Salim F, Keyvani H, Monavari SH, Alavian SM, Madjd Z, Toosi MN, et al. Occult hepatitis C virus infection in Iranian patients with cryptogenic liver disease. J Med Virol. 2011;83(6):98995.

18. Farahani M, Bokharaei-Salim F, Ghane M, Basi A, Meysami P, Keyvani $\mathrm{H}$. Prevalence of occult hepatitis $C$ virus infection in Iranian patients with lymphoproliferative disorders. J Med Virol. 2013;85(2):235-40.

19. Schiano TD, Martin P. Management of HCV infection and liver transplantation. Int J Med Sci. 2006;3(2):79-83.

20. Zaghloul H, El-Sherbiny W. Detection of occult hepatitis C and hepatitis B virus infections from peripheral blood mononuclear cells. Immunol Invest. 2010;39(3):284-91.

21. Idrees M, Lal A, Malik FA, Hussain A, Rehman I, Akbar H, et al. Occult hepatitis $\mathrm{C}$ virus infection and associated predictive factors: the Pakistan experience. Infect Genet Evol. 2011;11(2):442-5.

22. Comar M, Dal Molin G, D'Agaro P, Croce SL, Tiribelli C, Campello C. HBV, HCV, and TTV detection by in situ polymerase chain reac- tion could reveal occult infection in hepatocellular carcinoma: comparison with blood markers. J Clin Pathol. 2006;59(5):526-9.

23. De Marco L, Gillio-Tos A, Fiano V, Ronco G, Krogh V, Palli D, et al. Occult HCV infection: an unexpected finding in a population unselected for hepatic disease. PLoS One. 2009;4(12)

24. De Marco L, Manzini P, Trevisan M, Gillio-Tos A, Danielle F, Balloco $\mathrm{C}$, et al. Prevalence and follow-up of occult HCV infection in an Italian population free of clinically detectable infectious liver disease. PLoS One. 2012;7(8)

25. Giannini C, Giannelli F, Zignego AL. Association between mixed cryoglobulinemia, translocation $(14 ; 18)$, and persistence of occult HCV lymphoid infection after treatment. Hepatology. 2006;43(5):1166-7.

26. Richiardi L, De Marco L, Gillio-Tos A, Merletti F, Fiano V, Palli D, et al. Persistent infection by HCV and EBV in peripheral blood mononuclear cells and risk of non-Hodgkin's lymphoma. Cancer Epidemiol. 2010;34(6):709-12.

27. Welker MW, Zeuzem S. Occult hepatitis C: how convincing are the current data? Hepatology. 2009;49(2):665-75.

28. Sefidi FJ, Keyvani H, Monavari SH, Alavian SM, Fakhim S, Bokharaei-Salim F. Distribution of Hepatitis C Virus Genotypes in Iranian Chronic Infected Patients. Hepatitis Monthly. 2013;13(1).

29. Stramer SL. Current risks of transfusion-transmitted agents: a review. Arch Pathol Lab Med. 2007;131(5):702-7.

30. Alavian SM, Gholami B, Masarrat S. Hepatitis C risk factors in Iranian volunteer blood donors: a case-control study. J Gastroenterol Hepatol. 2002;17(10):1092-7.

31. Falagas ME, Karydis I, Kostogiannou I. Percutaneous exposure incidents of the health care personnel in a newly founded tertiary hospital: a prospective study. PLoS One. 2007;2(2)

32. Castillo I, Bartolome J, Quiroga JA, Barril G, Carreno V. Hepatitis C virus infection in the family setting of patients with occult hepatitis C. J Med Virol. 2009;81(7):1198-203.

33. Melon S, Galarraga MC, Villar M, Laures A, Boga JA, de Ona M, et al. Hepatitis $C$ virus reactivation in anti-hepatitic $C$ virus-positive renal transplant recipients. Transplant Proc. 2005;37(5):2083-5.

34. Cortés-Mancera FM, Restrepo JC, Osorio G, Hoyos S, Correa G, MC $\mathrm{N}$. Occult hepatitis $\mathrm{C}$ virus infection in a retransplanted patients with liver failure of unknown etiology. Rev Col Gastroenterol. 2010;25:72-80.

35. Veillon P, Payan C, Picchio G, Maniez-Montreuil M, Guntz P, Lunel F. Comparative evaluation of the total hepatitis $C$ virus core antigen, branched-DNA, and amplicor monitor assays in determining viremia for patients with chronic hepatitis $C$ during interferon plus ribavirin combination therapy. J Clin Microbiol. 2003;41(7):3212-20.

36. Stankovi -Djordjevi D, Tasi G, Dini M, Miladinovi -Tasi N, Stojanovi P, Bogdanovi M. Hepatitis C virus (HCV) viremia in patients with indeterminate second-generation HCV recombinant immunoblot assay. 2007. 